\title{
Epidemiological study of respiratory disease in workers exposed to polyvinylchloride dust
}

\author{
C A SOUTAR, L H COPLAND, P E THORNLEY, J F HURLEY, J OTTERY, \\ W G F ADAMS, AND B BENNETT
}

From the Institute of Occupational Medicine, Edinburgh, and Imperial Chemical Industries Limited

ABSTRACT The respiratory health of workers exposed to polyvinylchloride (PVC) dust has been investigated in 818 men sampled from the work force of a factory manufacturing PVC. In a crosssectional survey, the lung function and prevalences of respiratory symptoms and chest radiographic abnormalities were compared with estimates of individual PVC dust exposures based on detailed occupational histories and current measurements of respirable PVC dust. Complaints of slight exertional dyspnoea were associated with PVC dust exposure, though age and smoking effects were much stronger. The forced expired volume in one second $\left(\mathrm{FEV}_{1}\right)$ and forced vital capacity (FVC) were inversely related to dust exposure after age, height, and smoking effects had been taken into account. This effect was seen principally in cigarette smokers, and there was suggestive evidence that PVC dust exposure and cigarette smoking interacted in the reduction of FEV ${ }_{1}$ and FVC. Gas transfer factor was not related to dust exposure. The chest radiographs were read according to the ILO U/C classification by three experienced readers. One reader recorded a low prevalence of small rounded opacities, and these were not related to age or dust exposure. Another reader recorded a higher prevalence of small rounded opacities category $0 / 1$ or more, and these were related to age but not to dust exposure. The third reader recorded the highest prevalence of small rounded opacities (though none greater than category $1 / 1$ ), and these were independently related both to age and to PVC dust exposure, indicating an effect of PVC dust on the appearances of the chest radiograph. These appearances were so slight that only the higher sensitivity of this reader in the interpretation of piofusion of small rounded opacities on the ILO U/C scale enabled detection of this effect of PVC dust. In conclusion, exposure to PVC dust is associated with some deterioration of lung function, slight abnormalities of the chest radiograph, and complaints of slight dyspnoea. The mean decline in $\mathrm{FEV}_{1}$ associated with the average dust exposure experienced in the study was small, though some of the men with higher dust exposures may have suffered clinically important loss of lung function as a result of their occupation.

The dust produced during the the manufacture of polyvinylchloride (PVC) includes a large proportion by number of small particles of respirable size. ${ }^{2}$ Administration of PVC dust to animals has been reported to cause inflammatory changes of the bronchioles and alveoli, including a proliferation of histiocytes and granulomatous lesions, ${ }^{3}{ }^{4}$ and PVC formulations have been found to have cytotoxic effects in vitro. ${ }^{5-1}$ These effects were caused in part by the plasticisers, stabilisers, and other additives in the PVC, and there is some evidence that the in vitro toxicity of PVC

Address for reprint requests: Dr CA Soutar, Institute of Occupational Medicine, Roxburgh Place, Edinburgh EH8 9SU. dust is related to the presence of surfactant in the formulation. ${ }^{8} 9$

Case reports ${ }^{10} 11$ have described pathological $N$ changes in the lungs of workers exposed to PVC N dust. In several surveys of PVC workers increase of respiratory symptoms, abnormalities of lung function and of the chest radiograph have been $\stackrel{\odot}{\oplus}$ described, although these findings have been dif- $\stackrel{\mathscr{P}}{+}$ ficult to evaluate, principally because of lack of 0 satisfactory control groups, failure to take ade- 0 quate account of the effects of age, cigarette $\mathbb{\mathbb { D }}$ smoking, or general atmospheric pollution, and $\mathbb{D}$ lack of clarity in descriptions of radiographic readings. ${ }^{212-15}$ 


\section{Methods}

STUDY POPULATION

The sample to be studied was selected in January 1979 from 1501 currently employed men, 339 pensioners (men who received a pension from the manufacturer, most of whom were over 60 years of age) who had retired since 1 January 1967, and 468 men leaving for other reasons since that date.

Men were selected for study according to broad categories of cumulative dust exposure derived from factory records and preliminary estimates of dustiness based on inspection of the plant and measurements of size ranges of typical PVC dusts. The sampling scheme aimed to include all men with heavier dust exposures, and lesser proportions of those with lighter exposures. One hundred and fifty-six men with high or moderate dust exposures did not attend for survey, and were replaced by reserves drawn from moderately exposed groups.

Finally 818 men were studied, comprising 663 currently employed men, 98 pensioners, and 57 men who had left for reasons other than retirement ("leavers"). Single breath gas transfer for carbon monoxide was measured in 332 men sampled proportionally but randomly from each exposure category.

\section{ENVIRONMENTAL SURVEY}

Current personal exposures to respirable PVC dust were measured by occupation in each plant in which PVC was manufactured or processed. Preliminary estimates of dustiness were based on subjective observation by the sampling team and on particle size measurements of typical suspension and emulsion PVC dusts, and the major sampling effort was directed towards the apparently more dusty occupations in the drying, packing, and mixing areas.

One hundred and thirty reliable personal samples of respirable PVC dust were obtained from men in $\mathbf{4 4}$ different occupations for full shif $t$ periods on Sartorius cellulose ester membrane filters (type 11301), diameter $37 \mathrm{~mm}$, pore size $8.0 \mu \mathrm{m}$, inserted into a Casella Simpeds 70 cyclone. " This device samples a "respirable" fraction of airborne dust in accordance with the Johannesburg Convention, ${ }^{17}$ including $100 \%$ of all particles with an equivalent aerodynamic diameter of $1 \mu \mathrm{m}, 50 \%$ of those of $5 \mu \mathrm{m}$, and none greater than $7 \mu \mathrm{m}$.

MEDICAL SURVEY

A full occupational history was recorded, and the Medical Research Council Questionnaire of Respiratory Symptoms ${ }^{18}$ was administered by a trained clerk.

Forced expiratory volume in one second $\left(F_{1}\right)$ and forced vital capacity (FVC) were measured using a modified Gaensler spirometer. ${ }^{19}$ The best of three measurements was used for the analysis.

Single breath transfer factor for carbon monoxide (TLCO) was measured by the breathholding method $^{20}$ based on the modified Krogh technique (Transfer test B, PK Morgan Ltd., Chatham, Kent). Effective alveolar volume $\left(V_{A}\right)$ was measured by helium dilution in the same single breath, and used in the calculation of TLCo and Kco. The means of two observations were used in the analysis of these measurements. A full-size postero-anterior chest radiograph was taken by a standard technique $(95-120 \mathrm{kV})$.

The chest radiographs were read independently using the ILO U/C International Classification of Radiographs of Pneumoconioses ${ }^{21}$ by three readers highly experienced in this work. The readers had all been shown previously to produce readings that correlated with measurements of dust exposure in coalminers and to be highly consistent in their readings when presented with the same films on separate occasions. They did, however, represent a range of interpretation of profusion of small opacities recorded using the ILO U/C scale, and were known to differ consistently from each other in the prevalences of small rounded opacities they recorded.

\section{PVC DUST INDEX}

Every occupation within the population under study was allotted a PVC dust concentration on the basis of the measured current dust levels. Sixty-six such job/dust categories were derived from the measurements made and from knowledge of the factory conditions.

A "dust index" was derived from the current dust measurements and the occupational history such that the current dust levels in each of a man's occupations in the plastics factory was multiplied by the years he had spent in that occupation, and this figure added to the figures derived from his other occupations in the factory.

\section{STATISTICAL METHODS}

The data were studied initially by cross-tabulations, graphical methods, and summary descriptive statistics. Multiple linear regression analyses of the lung function results were carried out, with subsequent examination of residuals. The radiographic and respiratory symptoms results were studied by maximum likelihood logistic analysis. ${ }^{22}$ 


\section{Results}

ENVIRONMENTAL SURVEY

Respirable dust levels were highest in the older plants and those making polymer by the emulsion method. The highest mean average respirable dust exposure for any occupation over a shift was $2.88 \mathrm{mg} / \mathrm{m}^{3}(\mathrm{SD} \pm 1.84)$. The distribution of calculated dust indices (years $\times \mathrm{mg} / \mathrm{m}^{3}$ ) for the 818 men studied in the medical survey is shown in fig 1 .

\section{MEDICAL SURVEY}

Features of the population of 818 men are set out in tables 1 and 2 .

It was noted in preliminary analysis that the number of years worked at the PVC works or work in an outside industry in which noxious materials were used were of trivial importance in explaining the prevalence of symptoms, lung function and radiographic abnormality, after index of dust exposure, age, and smoking habit had been taken into account.

\section{Respiratory symptoms}

Analysis of respiratory symptoms was based on the answers to the questionnaire.

Two hundred and fifteen men (26\%) admitted to dyspnoea on exertion grade 1 ("shortness of breath when hurrying on level ground or walking up a slight hill"). Prevalence was approximately three times higher in the smoking groups (32\% in cigarette smokers) than in the non-smokers
Table 1 Features of 818 men studied, according to currently employed, pensioner, or other leaver status. 등 Dust index is expressed in years $\times \mathrm{mg} / \mathrm{m}^{s}$, but does not represent actual dust exposure, since only current $\overparen{\mathrm{D}}$ dust levels are known

\begin{tabular}{|c|c|c|c|}
\hline & Current worker & s Pensioners & Leavers \\
\hline Number & 663 & 98 & 57 \\
\hline $\begin{array}{l}\text { Mean age (yrs) } \\
\text { (SD) }\end{array}$ & $\begin{array}{c}44 \cdot 2 \\
(10 \cdot 8)\end{array}$ & $\begin{array}{l}63 \cdot 4 \\
(7 \cdot 1)\end{array}$ & $\begin{array}{c}43 \cdot 2 \\
(10 \cdot 2)\end{array}$ \\
\hline $\begin{array}{l}\text { Mean height (cm) } \\
\text { (SD) }\end{array}$ & $\begin{array}{r}173 \cdot 0 \\
(6 \cdot 5)\end{array}$ & $\begin{array}{r}170 \cdot 2 \\
(5 \cdot 4)\end{array}$ & $\begin{array}{r}171 \cdot 2 \\
(6 \cdot 2)\end{array}$ \\
\hline $\begin{array}{l}\text { Mean weight }(\mathrm{Kg}) \\
\text { (SD) }\end{array}$ & $\begin{array}{r}77 \cdot 7 \\
(10 \cdot 5\end{array}$ & $\begin{array}{c}75 \cdot 6 \\
(10 \cdot 8)\end{array}$ & $\begin{array}{c}77 \cdot 4 \\
(13 \cdot 5)\end{array}$ \\
\hline $\begin{array}{l}\text { Mean dust index } \\
\text { (SD) }\end{array}$ & $\begin{array}{c}13.39 \\
(12.84)\end{array}$ & $\begin{array}{c}14 \cdot 23 \\
(11 \cdot 86)\end{array}$ & $\begin{array}{c}4.86 \\
(6.69)\end{array}$ \\
\hline $\begin{array}{l}\text { Years at the plant } \\
\text { (SD) }\end{array}$ & $\begin{array}{l}14 \cdot 34 \\
(8 \cdot 48)\end{array}$ & $\begin{array}{l}16 \cdot 63 \\
(8.06)\end{array}$ & $\begin{array}{c}5.46 \\
(5 \cdot 48)\end{array}$ \\
\hline $\begin{array}{l}\text { Mean FEV }_{1} \text { (1) } \\
\text { (SD) }\end{array}$ & $\begin{array}{c}3.54 \\
(0.83)\end{array}$ & $\begin{array}{c}2.43 \\
(0.73)\end{array}$ & $\begin{array}{c}3.53 \\
(0.72)\end{array}$ \\
\hline $\begin{array}{l}\text { Mean FVC (I) } \\
\text { (SD) }\end{array}$ & $\begin{array}{l}4.62 \\
(0.88)\end{array}$ & $\begin{array}{c}3.41 \\
(0.78)\end{array}$ & $\begin{array}{l}4.54 \\
(0.80)\end{array}$ \\
\hline $\begin{array}{l}\text { Mean FEV } \mathrm{FEV}_{1} / \mathrm{FVC} \\
\text { (SD) }\end{array}$ & $\begin{array}{c}0.76 \\
(0.08)\end{array}$ & $\begin{array}{l}0 \cdot 70 \\
(0 \cdot 11)\end{array}$ & $\begin{array}{c}0.78 \\
(0.06)\end{array}$ \\
\hline
\end{tabular}

(10\%). A strong age effect was also apparent, $\vec{\oplus}$ prevalence approximately doubling for every 13. years of age in this population. A dust effect was indicated $(p=0.054)$ after adjustment for age and smoking, and this effect was clear in current cigarette smokers $(\mathrm{p}<0.02,10$ dust index units® increased the estimated prevalence by a factor ${ }^{\Phi}$ of about $20 \%$ ) after allowing for age and life- $\vec{z}$ time cigarette consumption. The dust effect was 3 not demonstrated in the other smoking cate- $\vec{T}$ gories, though these differences between smokingo categories could have arisen by chance $(p<0.5)$.

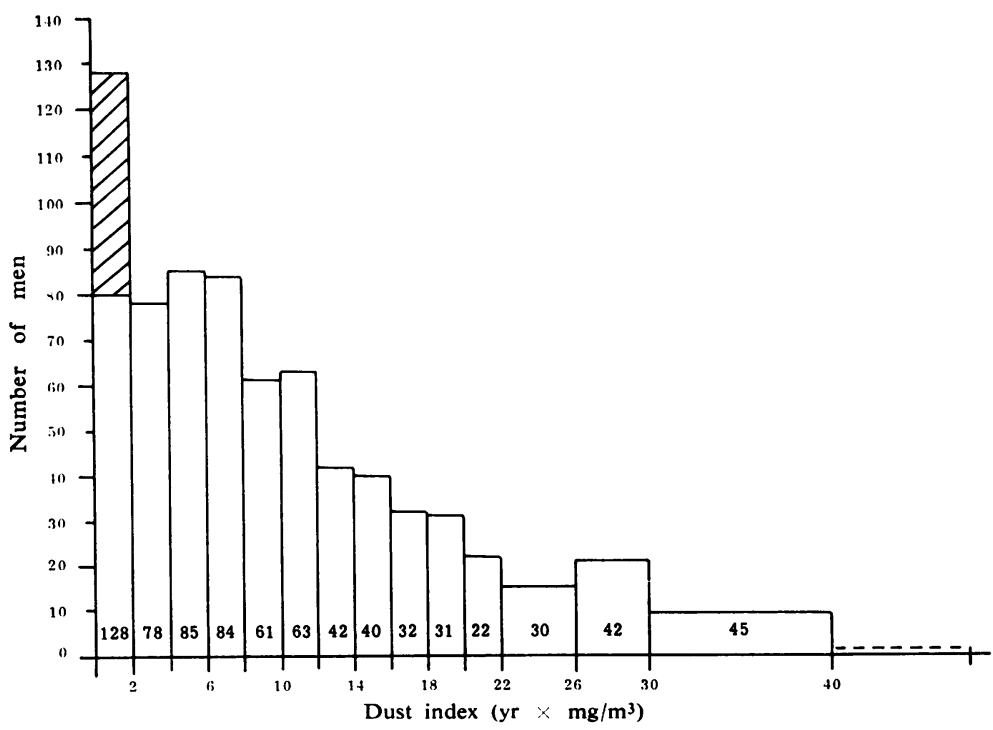

Fig 1 Frequency of dust indices. number of men with dust exposure $=0$. 
Table 2 Numbers of men and (mean dust indices) of 818 men grouped by age and smoking category. Units of dust indices are years $\times \mathrm{mg} / \mathrm{m}^{3}$

\begin{tabular}{|c|c|c|c|c|c|c|c|}
\hline & \multicolumn{7}{|c|}{ Age groups (yr) } \\
\hline & $<35$ & $35-44$ & $45-49$ & $50-54$ & $55-59$ & $60+$ & All \\
\hline Non-smokers & $50(4 \cdot 1)$ & $41(6 \cdot 7)$ & $16(8 \cdot 2)$ & $16(12 \cdot 3)$ & $5(15.4)$ & $20(15 \cdot 2)$ & $148(8 \cdot 0)$ \\
\hline Cigarette smokers & $65(5 \cdot 2)$ & $97(12 \cdot 0)$ & $60(16 \cdot 4)$ & $60(16 \cdot 6)$ & $55(18.4)$ & $41(16.9)$ & $378(13.7)$ \\
\hline Other s.nokers & $3(3.0)$ & $11(14 \cdot 7)$ & $12(13.8)$ & $9(19 \cdot 4)$ & $12(19 \cdot 1)$ & $11(11 \cdot 7)$ & $58(15 \cdot 0)$ \\
\hline Ex-smokers & $37(6 \cdot 6)$ & $48(12.9)$ & $35(14 \cdot 5)$ & $41(16 \cdot 5)$ & $31(16 \cdot 3)$ & $42(18 \cdot 1)$ & $234(14 \cdot 2)$ \\
\hline All & $155(5 \cdot 2)$ & $197(11 \cdot 3)$ & $123(14 \cdot 5)$ & $126(16 \cdot 2)$ & $103(17 \cdot 7)$ & $114(16 \cdot 5)$ & $818(12.9)$ \\
\hline
\end{tabular}

No relationships were demonstrated between dust index and history of chronic cough or sputum, asthma or history or acute chest illness.

\section{Forced expired volume in one second}

Preliminary analysis indicated different rates of loss of $\mathrm{FEV}_{1}$ because of age between the smoking categories, and different mean levels of $\mathrm{FEV}_{1}$ according to current, pensioner, or leaver employment status. These differences were taken into account in the regression model, which also took account of height, weight, and lifetime cigarette consumption.

Within this framework index of dust exposure was significantly inversely related to $F_{1}$ $(p<0.025)$ (table 3). Neither the estimated size nor the significance of the regression with dust index was seriously altered when alternative models of age and smoking were examined.

More detailed analysis examined whether the effect of dust index varied according to smoking category and job status groups (current workers, pensioners, or leavers). Though the observed differences in dust effect in these groups could have arisen by chance $(p \bumpeq 0.45)$ the numbers of men in some of the subgroups are small, and the pattern of positive and negative effects suggested an interaction between dust effect, current employment at the factory, and cigarette smoking (table 4). The dust effect was seen principally in currently employed cigarette smokers.

After taking into account the effects of age,

Table 3 Regression of FEV ${ }_{1}$. Different intercepts for employment and smoking categories allowed but not shown

\begin{tabular}{|c|c|c|c|}
\hline \multicolumn{2}{|l|}{ Variable } & $\begin{array}{l}\text { Regression } \\
\text { Coefficient }\end{array}$ & $p$ \\
\hline $\begin{array}{l}\text { Height }(\mathrm{cm}) \\
\text { Weight }(\mathrm{kg}) \\
\text { Age }(\mathrm{yr})\end{array}$ & $\left\{\begin{array}{l}\text { non-smokers } \\
\text { ex-smokers } \\
\text { other smokers } \\
\text { cigarette smokers }\end{array}\right.$ & $\begin{array}{r}0.0434 \\
-0.0032 \\
-0.0260 \\
-0.0350 \\
-0.0489 \\
-0.0392\end{array}$ & $\begin{array}{l}<0.0001 \\
<0.2 \\
<0.0001 \\
<0.0001 \\
<0.0001 \\
<0.0001\end{array}$ \\
\hline \multicolumn{2}{|c|}{$\begin{array}{l}\text { Lifetime cigarette consumption } \\
\text { ( } 1000 \text { packs) } \\
\left.\text { Dust index (years } \times \mathrm{mg} / \mathrm{m}^{3}\right)\end{array}$} & $\begin{array}{r}0.0154 \\
-0.0041\end{array}$ & $\begin{array}{l}<0.0001 \\
<0.025\end{array}$ \\
\hline
\end{tabular}

height, weight, and smoking habits (the model in table 3), the overall loss of $\mathrm{FEV}_{1}$ associated with one dust index unit (years $\times \mathrm{mg} / \mathrm{m}^{3}$ ) was estimated as 0.0041 litres. This would be equivalent to a loss of $53 \mathrm{ml}$ of $\mathrm{FEV}_{1}$ for the mean dust index, additional to the estimated losses caused by age and smoking ( $26 \mathrm{ml}$ per year in nonsmokers, $39 \mathrm{ml}$ per year for cigarette smokers plus an additional $5.6 \mathrm{ml}$ per year for each packet of cigarettes smoked per day throughout the year).

In currently employed cigarette smokers considered separately (the model in table 4), the loss associated with dust index was estimated as 84 mls of $\mathrm{FEV}_{1}$ for similar exposure, additional to the loss caused by smoking and age. The mean $\mathrm{FEV}_{1}$ loss in this group of men in relation to high dust exposure (40 dust index units or more, experienced by only $4.3 \%$ of all the men) was estimated at $260 \mathrm{ml}$.

Forced vital capacity

A similar sequence of analysis to that for FEV was followed, with qualitatively similar results. There was a negative effect of dust index on FVC $(\mathrm{p}<0 \cdot 1)$.

Further analysis of dust effect in the smoking and job category subgroups again showed a significant adverse dust effect in cigarette smokers

Table 4 Regression coefficients for dust index against FEV ${ }_{1}$. Expansion of model of regression for $F E V_{1}$ illustrated in table 3.

Coefficients and significance of concomitant variables changed little from the model described in table 3. $N S=$ not significant at the $10 \%$ level

\begin{tabular}{|c|c|c|c|c|}
\hline & $\begin{array}{l}\text { Cigarette } \\
\text { smokers }\end{array}$ & $\begin{array}{l}\text { Other } \\
\text { smokers }\end{array}$ & Ex-smokers & Non-smokers \\
\hline $\begin{array}{l}\text { Current } \\
\text { workers } \\
\text { (number) }\end{array}$ & $\begin{array}{c}-0.0065 \\
(312) \\
(p<0.02)\end{array}$ & $\begin{array}{l}-0.0023 \\
N S^{(47)}\end{array}$ & $\begin{array}{l}-0.0024 \\
(185) \\
\text { NS }\end{array}$ & $\begin{array}{l}-0.0034 \\
(119) \\
\text { NS }\end{array}$ \\
\hline $\begin{array}{l}\text { Leavers } \\
\quad \text { (number) } \\
\text { Pensioners } \\
\text { (number) }\end{array}$ & $\begin{array}{c}-0.0278 \\
(25) \\
(p<0.08) \\
-0.0018 \\
(41) \\
N S\end{array}$ & $\begin{array}{c}0.0468 \\
(3) \\
\text { NS } \\
-0.0154 \\
N^{(8)}\end{array}$ & 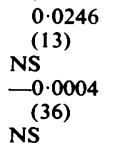 & $\begin{array}{l}0.0118 \\
(16) \\
\text { NS } \\
0.0179 \\
(13) \\
\text { NS }\end{array}$ \\
\hline
\end{tabular}


Table 5 Prevalence of categories of small opacities found by three readers in 818 chest radiographs. Radiographs in which both rounded and irregular opacities were found are also represented here in the rounded and irregular categories

\begin{tabular}{|c|c|c|c|c|c|}
\hline \multirow{2}{*}{ Reader } & \multicolumn{2}{|l|}{ Small rounded opacities } & \multicolumn{2}{|l|}{ Small irregular opacities } & \multirow{2}{*}{$\begin{array}{l}\begin{array}{l}\text { Both rounded and } \\
\text { irregular opacities }\end{array} \\
\text { Category } 0 / 1 \text { or mo }\end{array}$} \\
\hline & Category $0 / 1$ or more & Category $1 / 0$ or more & Category $0 / 1$ or more & Category 110 or more & \\
\hline $\begin{array}{l}3 \\
15 \\
17\end{array}$ & $\begin{array}{r}18(2 \cdot 20 \%) \\
4(0 \cdot 49 \%) \\
50(6 \cdot 11 \%)\end{array}$ & $\begin{array}{r}2(0.24 \%) \\
2(0.24 \%) \\
10(1.22 \%)\end{array}$ & $\begin{array}{l}32(3.91 \%) \\
53(6.48 \%) \\
29(3.55 \%)\end{array}$ & $\begin{array}{r}7(0.36 \%) \\
46(5.62 \%) \\
8(0.98 \%)\end{array}$ & $\begin{array}{l}4(0.49 \%) \\
0(0.00 \%) \\
4(0.47 \%)\end{array}$ \\
\hline
\end{tabular}

currently working at the factory $(p<0.03)$. The observed differences in dust effect in these groups could easily have arisen by chance, but an interaction between dust effect, current employment, and cigarette smoking was suggested, broadly similar to that for the $\mathrm{FEV}_{1}$.

\section{Other measurements of respiratory function}

The FEV 1 FVC ratio, TLCo, Kco, and $V_{A}$ were not significantly related to index of PVC dust exposure, nor was any sizeable effect indicated.

\section{Chest radiographs}

Small rounded opacities The anticipated differences between readers in interpretation of small opacities were apparent (table 5). Reader 17 recorded the greatest prevalence of small rounded opacities: 50 radiographs $(6 \cdot 1 \%)$ with category $0 / 1$ or more, $10(1.2 \%)$ with category $1 / 0$ or more, the latter consisting of six radiographs with category $1 / 0$ and four with category $1 / 1$. Among these 50 radiographs, there was a strong association between classification by reader 17 as category $1 / 0$ or more and classification by either reader 3 or 15 as small rounded opacities cate- gory $0 / 1$ or more (chi-square test, $\mathrm{p}<0.001$ \% confirming that inter-reader differences in inteio pretation of small rounded opacities were differ ences of degree, rather than classification of unrelated appearances.

The readings for readers 3 and 17 showeep clear relationships between prevalence of smal rounded opacities and age $(\mathrm{p}<0.002$ and $\mathrm{p}<0.009$ respectively). The observed data are set out is fig 2. For reader 3, after age had been taken into account, there was no relationship with dus exposure $(p=0.83)$. For reader 17 there was $\Phi$ strong dust effect even after age had been takeף into account $(\mathrm{p}<0.001,10$ dust index unit increased the estimated prevalence by a facto of about $35 \%$ ). Observed data are set out in fig The dust effect varied according to smoking status $(p<0.02)$, and was not observed among current cigarette smokers although the age effeç was marked. The reason for these differences was not apparent.

Reader 17 recorded 10 radiographs showing small rounded opacities category $1 / 0$ or greate and in spite of this small number, a significan relationship with both age $(p<0.005)$ and dust

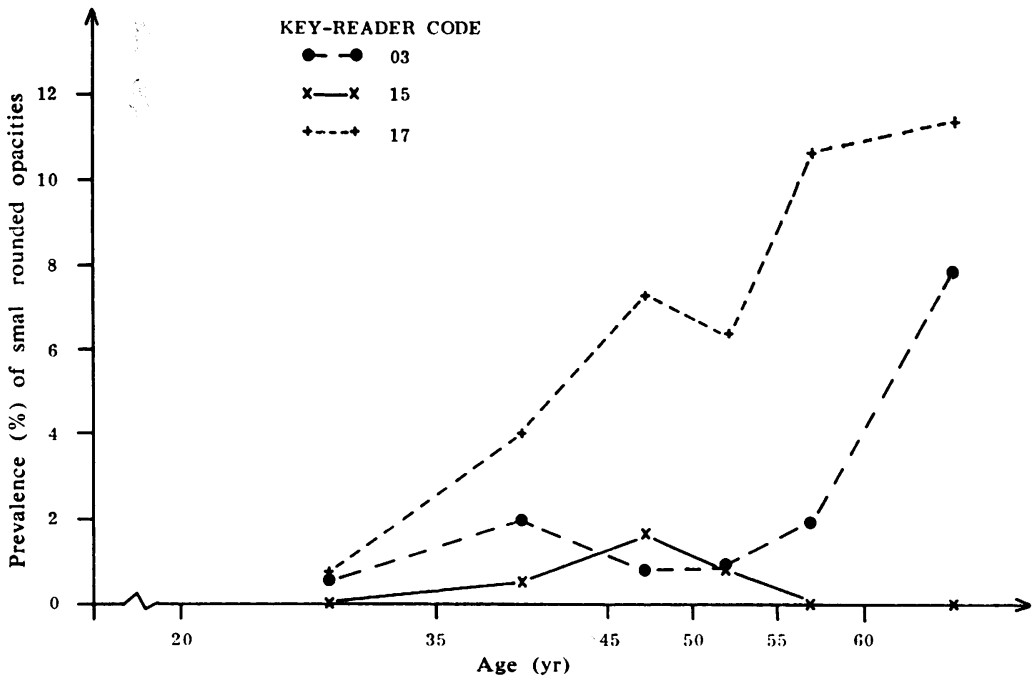

Fig 2 Prevalence of small N roun!ed opacities category $0 / N$ or more found by three readers related to age group. 


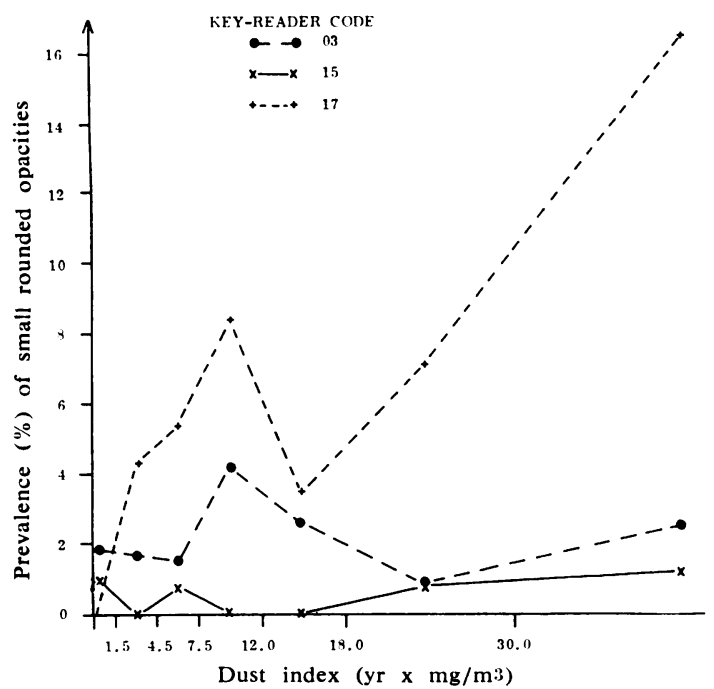

Fig 3 Prevalence of small rounded opacities category $0 / 1$ or more found by three readers, related to dust index.

index $(\mathrm{p}<002)$ (after adjusting for the other) was found.

Reader 15 classified only four radiographs as showing small rounded opacities: these classifications were unrelated to age or dust exposure. Small irregular opacities Analysis showed a clear relationship between prevalence of small irregular opacities category $0 / 1$ or greater and age for all three readers (fig 4) $(p<0.001$ for each reader). There was no relationship of prevalence of small irregular opacities with dust index for any of the three readers.

For reader 15 the relationship of small irregular opacities with age could in small part be explained by a positive history of chronic cough or sputum $(p<0.03)$, and by history of chest illness $(p<0.03)$. Reader 17 also found a relationship of small irregular opacities with chronic cough or sputum $(\mathrm{p}<0.06)$, but no relationship with history of chest illness. For both readers, the age effect remained extremely strong even when these symptoms were taken into account.

Reader 3 found differences between smoking categories. Prevalence of small irregular opacities was lowest in non-smokers $(0.7 \%)$ and highest among other smokers $(12 \cdot 1 \%)$. These were not accounted for by the different age distributions of the smoking groups. There was no dust effect. Neither of the other two readers identified smoking differences.

Relationship of lung function to the presence of small rounded opacities Reader 17 recorded small rounded opacities category $0 / 1$ or greater in 50 radiographs. The lung function of these men was significantly reduced. The FEV

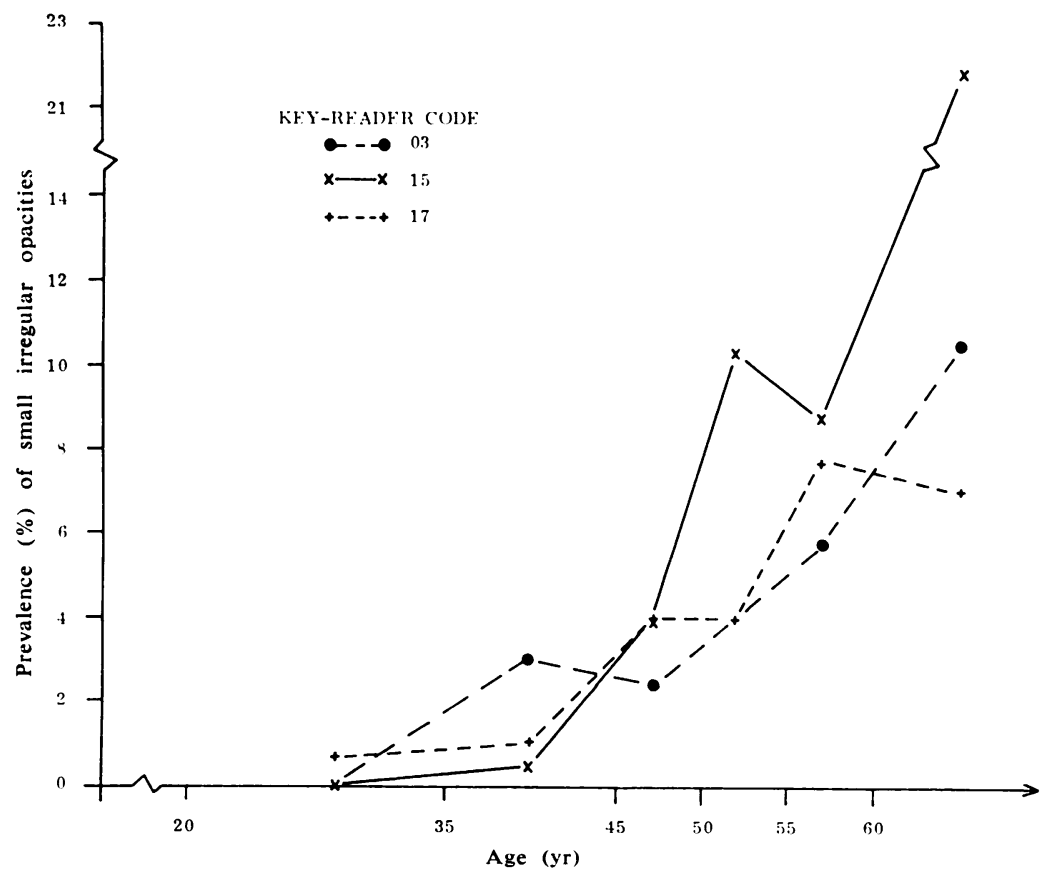

Fig 4 Prevalence of small irregular opacities category $0 / 1$ or more found by three readers, related to age. 
was reduced by a mean of $206 \mathrm{ml}(\mathrm{p}<0.02$ after age, height, weight, smoking, cigarette consumption, and dust index had been taken into account (the less complex model described in table 3). The FVC was reduced by a mean of $253 \mathrm{ml}(\mathrm{p}<0.01)$, using the same model, and $\mathrm{FEV}_{1} / \mathrm{FVC}$ ratio analysed on the log scale was not significantly reduced. TLCO and Kco were measured in 21 of these men, and were not found to be significantly reduced. $V_{A}$ was reduced in these 21 men by a mean of $309 \mathrm{ml}(\mathrm{p}<0.05)$.

\section{Relationship of lung function to the presence of small irregular opacities}

Radiographs of 90 men were thought by one or more readers to show small irregular opacities $0 / 1$ or greater. The lung function of these men was significantly reduced. Their mean $\mathrm{FEV}_{1}$ was reduced by $205 \mathrm{ml}(\mathrm{p}<0.01)$ after adjusting for age, height, weight, smoking category, lifetime cigarette consumption, and dust index (the model in table 3). The mean FVC was reduced by 142 $\mathrm{ml}$, using a similar model $(\mathrm{p}<0 \cdot 10)$. The ratio $\mathrm{FEV}_{1} / \mathrm{FVC}$ was also significantly reduced $(\mathrm{p}<0.01$, by a factor of 0.97 ). TLCO was measured in 45 of these men, and was reduced by a mean of $1.52 \mathrm{ml} / \mathrm{min} \mathrm{mmHg}(\mathrm{p}<0.05)$. $\mathrm{V}_{\mathrm{A}}$ and $\mathrm{KcO}$ were not significantly reduced.

\section{Autoclave workers}

The effect of a history of work on the autoclaves (where exposure to vinylchloride monomer may have occurred in the past) was examined in the respiratory symptoms, lung function, and chest radiographic abnormality models. A history of having been an autoclave worker had no demonstrable adverse influence on symptoms, lung function, or chest radiographic abnormalities. Thus there was no evidence that apparent PVC dust effects were the result of exposure to vinylchloride monomer during autoclave working.

\section{Clinical readings of chest radiographs}

The chest radiograph of one man showed advanced diffuse pulmonary fibrosis. This man had a chest radiograph taken though he was not in the intended study sample. The relevance of his disease to his work is currently being investigated, but has not yet been established. No cases of lung cancer or active tuberculosis were detected in the survey.

\section{Discussion}

This study was planned to compare the lung function, chest radiographic appearances, ang prevalence of respiratory symptoms in worke in a factory manufacturing PVC with estimate of personal exposure to respirable PVC dust. $~$

The random sample was selected from men who had previously worked in the factory as well as the current work force, and was weighted to include a relatively high proportion of those who had the highest lifetime exposure to PV dust. These preliminary estimates of exposure were based on factory records and a preliminare inspection of the plants and typical dusts prob duced. Twenty-five per cent of selected merf thought on this basis to have high or moderate exposures, did not attend for examination? Reserves for these men were included, albeit that these were from medium rather than higm dust exposure groups, to ensure that sufficient numbers of men with substantial exposures wero studied. It is emphasised that the dust exposure estimates used in the analysis were not based on these preliminary estimates but on a detaileक occupational history obtained from each man together with measurements of current personæ exposures in the factory. These estimates, thoug the best available, may nevertheless have beeo inaccurate to the extent that previous dust exp posures may have been higher than those presently experienced. In view of probable ove $\overrightarrow{\vec{b}}$ all changes in dust levels conclusions about quan titative relationships between dust and disease should be drawn with caution.

It was not possible in this study to tak account of the health effects of the componen of the PVC powder other than the PVC itsele nor of changes in the formulation occurring over the years. The "respirable" fraction of ait borne dust measured in this survey is suitable for compariscns with both bronchial and alveolat disease, for dust in this size range deposio substantially either in bronchial or alveolap zones. Furthermore, measured exposure to "res. pirable" coal mine dust has been shown tro correlate with mucous hypersecretion and loss of $\mathrm{FEV}_{1}$ in miners, ${ }^{23}{ }^{24}$ as well as with the radien graphic appearances of pneumoconiosis. ${ }^{25}$ స

The study demonstrated a relationship betwee estimates of exposure to PVC dust and dyspnoeeg lung function, and chest radiological abnormality A history of moderate exertional dyspnoea was related to dust exposure, though this relationship was apparent only in cigarette smokers. Th8 effect was additional to the effects of smoking and aging which were, however, the predominaris explanatory variables for this symptom. It seeng unlikely that the effect of PVC dust on symptoms 
alone is of much clinical importance. PVC dust exposure was related to reduction of $\mathrm{FEV}_{1}$ and FVC but not of transfer factor or alveolar volume. The mean decline of $\mathrm{FEV}_{1}$ related to dust exposure was small, though individual variations in response might be expected to have caused clinically significant loss of lung function in some of the men with high dust exposures. The effect of dust on lung function was seen mostly in cigarette smokers, an apparent interaction which could have arisen by chance but which was supported by the pattern of dust effects among the various smoking categories. Respiratory disease has been reported in food wrappers cutting PVC film with hot wires, ${ }^{26}$ and in one report these symptoms appeared to be more common in workers who smoked cigarettes. $^{27}$ It is conceivable that the apparent interaction between smoking and PVC dust exposure reported in the present study was an effect of products of combustion of cigarettes contaminated with PVC dust from contact with dusty hands or clothing, though there was no direct evidence from this study of such a mechanism.

Assessments of the profusion of small opacities in chest radiographs according to the ILO U/C Classification are known to vary between readers. The three experienced readers invited to take part in this study were each known to show little variability on repeated readings of the same radiographs, but were also known to differ consistently from each other in the prevalences of small rounded opacities they recorded. In the present study the anticipated differences between readers were again apparent. One reader recorded small rounded opacities in very few chest radiographs, and these were not obviously related to age or dust exposure. Another reader recorded small rounded opacities in a larger number of men, and presence of these opacities was correlated with age but not dust exposure. The third reader recorded the greatest prevalence of small rounded opacities, and it was found that these opacities were related to age and, independently, to dust exposure. We consider each of these readers' assessments to be scientifically valid, and that the third reader's more sensitive interpretation of the recognition and recording of small rounded opacities enabled the detection of a relationship between radiographic appearances and dust exposure. The profusions of these small rounded opacities were almost all of low category (none greater than $1 / 1$ ), and the slightness of these appearances was corfirmed by the other readers, who in many cases did not even record their presence. On clinical readings of the radiographs there were no cases of advanced pulmonary fibrosis among them, except for one man, not in the study population, who did have radiographic evidence of advanced pulmonary fibrosis. Further investigation of the cause of this is being undertaken.

Thus PVC dust exposure was associated with both small rounded opacities on the chest radiograph and a slight average functional defect. The reduction of $\mathrm{FEV}_{1}$ but normal alveolar volume and transfer factor indicated that the effect was predominantly obstructive in type, but the parallel reduction of FVC indicated by the lack of any relationship between dust exposure and the ratio between $F E V_{1}$ and $F V C$ suggested a slight additional element of restriction. The radiological and functional abnormalities were themselves related, for the 50 men with small rounded opacities also had reductions of $\mathrm{FEV}_{1}, \mathrm{FVC}$, and alveolar volume after the effect of dust had been allowed for. While this relationship was not specific for PVC dust effects, for it was seen predominantly among cigarette smokers whose small opacities were not obviously related to dust exposure, it does tend to suggest that small rounded opacities may be the result of disease of bronchioles, sufficiently distal to be radiologically detectable yet sufficiently proximal to cause an obstructive defect. The parallel reductions of FVC and $V_{A}$ suggest an additional restrictive defect, which tends to confirm the distal site of the lung damage, the nature of which might be similar to the cellular reaction reported in one case of a PVC worker with radiographic shadows. ${ }^{11}$

By contrast, small irregular opacities, related to age and in small part to chronic productive cough but not to dust exposure, were associated with a more classical obstructive pattern in which the $\mathrm{FEV}_{1}$ was reduced substantially more than the FVC. There was in addition a reduction of gas transfer factor suggesting the presence of emphysema or ventilation/perfusion mismatching. Since the later stages of panacinar emphysema are usually associated with a diminution rather than an increase in radiographic lung shadows, it is probable that the clinical recognition of small irregular opacities enables the identification of a type of chronic airflow obstruction associated with ventilation/perfusion mismatching. The pathological basis for the opacities might conceivably be enlarged arteriovenous shunts.

We conclude that exposure to PVC dust is associated with abnormalities of lung function, 
slight abnormalities of the chest radiograph and complaints of slight dyspnoea. While these results are not unduly alarming, they do indicate that PVC dust exposure should be controlled, and that the men with radiographic abnormalities should be followed clinically to determine future progression or regression of the condition.

This study was carried out with the full cooperation of the management and workforce of Imperial Chemical Industries Limited to whom we are grateful for financial support. We are grateful to Dr JA Dick, Dr JG Bennett, and Dr DJ Thomas for the epidemiological radiographic readings, and to $\mathrm{Dr} A$ Seaton, $\mathrm{Dr} M$ Jacobsen, and $\mathrm{Mr} \mathrm{J}$ Dodgson for much advice and help. Further details of the results of this work are recorded in Institute of Occupational Medicine Technical Memorandum TM/79/2.

\section{References}

1 Casula D, Cherchi P, Spiga G, Spinazzola A. Environmental dust in a plant for the production of polyvinylchloride. Ann Inst Super Sanita 1977; 13:189-98.

2 Mapp C, Fabbri L, Rossi A, Moro G, Cervi G. Alterazioni funzionali respiratorie da esposizione cronica a cloruro di vinile monomero e polimero. Med Lav 1978; 69:151-62.

3 Frongia N, Spinazzola A, Bucarelli A. Lesioni polmonari sperimentali da inalazione prolungata di PVC in ambiente di lavoro. Med Lav 1974; 65:321-42.

4. Agarwal DK, Kaw JL, Srivastava SP, Seth PK. Some biochemical and histopathological changes induced by polyvinylchloride dust in rat lung. Environ Res 1978; 16:333-41.

5 DeHaan RL. Toxicity of tissue culture media exposed to polyvinylchloride plastic. Nature New Biol 1971; 231:85-6.

6 Salthouse TN, Matlaga BF, O'Leary RK. Microspectrophotometry of macrophage lysosomal enzyme activity: a measure of polymer implant tissue toxicity. Toxicol Appl Pharmacol 1973; 25:201-11.

7 Richards RJ. Desai R, Hext PM. Rose FA, Biological reactivity of PVC dust. Nature 1975; 256: 664-5.

8 Richards RJ, Desai R, Rose FA. A surface-active agent involved in PVC-induced haemolysis. Nature 1976; 260:53-4.

9 Piggott GH, Ishmael J. A comparison between in vitro toxicity of PVC powders and their tissue reaction in vivo. Ann Occup Hyg 1979; 22:11126.

10 Szende B, Lapis K, Nemes A, Pinter A. Pneumoconiosis caused by the inhalation of polyvinylchloride dust. Med Lav 1970; 61:433-6.
11 Arnaud A, Pommier De Santi P, Garbe L, Payare H, Charpin J. Polyvinylchloride pneumoconi osis. Thorax 1978; 33:19-25.

12 Miller A, Tirstein AS, Chuang M, Selikoff IJ Warshaw $R$. Changes in pulmonary function in workers exposed to vinyl chloride and polyvinyl chloride. Ann N Y Acad Sci 1975; 246:42-52. $\vec{\circ}$

13 Lilis $\mathbf{R}$, Anderson $\mathrm{H}$, Miller A, Selikoff $1 \mathrm{~J}-$ Pulmonary changes among vinyl chloride poly $\vec{\omega}$ merization workers. Chest 1976; 69:299-303.

14 Mastrangelo G, Manno M, Marcer G et al: Polyvinylchloride pneumoconiosis: epidemio logical study of exposed workers. J Occup Me\& 1979; 21:540-2.

15 Gamble J, Liu S, McMichael AJ, Waxweiler RJ Effect of occupational and nonoccupationab factors on the respiratory system of vinyl chloride and other workers. J Occup Med 1976; 18:659-70

6 McGuire BA, Barker D, Badel DA. SIMPEDSD 70: an improved version of the SIMPEDS per $\frac{\vec{D}}{D}$ sonal gravimetric dust sampling instrument. In: Walton WH, ed. Inhaled Particles III. Olक्ष Woking: Unwin Bros, 1970: 1053-7.

17 Orenstein AJ, ed. Proceedings of the Pneumo-e coniosis Conference. London: JA Churchillo 1960.

18 Medical Research Council. Report of the Work ing Party on Research into Chronic Bronchitis. London: Medical Research Council. 1976.

19 McKerrow CB, McDermott M, Gilson JC. A气̆ spirometer for measuring the forced expiratorio volume with a simple calibrating device. Lance $F$ 1960; 1:149-51.

20 Meade F, Saunders MJ, Hyett F, Reynolds JA Pearl N, Cotes JE. Automatic measurement of lung function. Lancet $1965 ; 2: 573-5$.

21 International Labour Office. Occupational Safety产 and Health. ILO International classification of radiographs of pneumoconioses 1971. Geneva: $: \times$ ILO, 1972: 22.

22 Cox DR. The analysis of binary data. London Methuen, 1970.

23 Rae S, Walker DD, Attfield MD. Chronic bron chitis and dust exposure in British coalminers. In:O을 Walton WH, ed. Inhaled Particles III. Old Woking: Unwin Bros, 1971: 883-94.

24 Rogan JM. Attfield MD, Jacobsen M, Rae $S_{\mathrm{N}}$ Walker DD, Walton WH. Role of dust in the working environment in development of chronion bronchitis in British coal miners. $\mathrm{Br} J$ Ind Mech 1973; 30:217-26.

25 Jacobsen M, Rae S, Walton WH, Rogan JM. The relation between pneumoconiosis and dust $\frac{\mathrm{Q}}{\mathrm{C}}$ exposure in British coal mines. In: Walton WHळ ed. Inhalet Particles III. Old Woking: Unwinf Bros, 1971: 903-19.

26 Sokol WN, Aelony Y, Beall GN. Meat-wrapper'응 asthma: a new syndrome. JAMA 1973; 226:639 41.

27 Falk H, Portnoy B. Respiratory illness in meato wrappers. JAMA 1976; 235:915-7. 